\title{
Change in Alkaline Phosphatase Activity Induced By Tetracycline in Freshwater Mussel, Parreysia cylindrica (Annandale and Prashad)
}

\author{
H. P. Nandurkar \\ (Department of Zoology, Sant Gadge Baba Amravati University, Amravati. (M.S.) 444 602, INDIA)
}

\begin{abstract}
Alkaline phosphatase is a non-specific hydrolase enzyme. This enzyme is responsible for transphosphorylation and has an important role in the general energetics of an organism. Internal milieu of the organ can be assessed by alteration in the enzymatic activity as it is a tool to indicate the stress offered by various chemical compounds. In the present study, Alkaline phosphatase activity is measured in a fresh water mussel Parreysia cylindrica after acute and chronic exposure to tetracycline, one of the broad spectrum antibiotics. $P$. cylindrica are exposed to $L C_{50 / 2}(166.54 P P M)$ for acute treatment upto $96 \mathrm{hrs}$ and $L C_{50 / 10}(33.30$ PPM) for chronic treatment upto 21 days in gills, mantle and digestive gland. In tetracycline exposed bivalves, alkaline phosphatase activity was greatly increased in gills $(+26.37 \%)$ than mantle and digestive gland while after chronic exposure it showed $25.32 \%$ increase upto $14^{\text {th }}$ day and then reached to $16.55 \%$ increase upto $21^{\text {st }}$ day in gills over control. The digestive gland showed least increase in alkaline phosphatase activity.
\end{abstract}

Keywords: Alkaline phosphatase activity, P. cylindrica, tetracycline

\section{Introduction}

In water bodies the contamination of different pollutants affects aquatic life through the change in different parameters of biomolecules. To reduce mortality of the freshwater bivalves during rearing and after bead implantation they are treated by antibiotic containing water. This is the reason to use tetracycline in the present study to find out the tetracycline based stress on the enzymatic parameter through alkaline phosphatase activity in bivalves. Alkaline phosphatase estimation is a bioindicator of this toxic effect of antibiotics. Through this paper an attempt is made to find out alkaline phosphatase activity under acute and chronic exposures of tetracycline. Alkaline phosphatase is a non-specific lysosomal hydrolase. These enzymes are responsible for transphosphorylation and have an important role in the general energetics of an organism. During cellular damage due to toxic stress by pollutants or heavy metals, phosphatase activity might be increase. Ranilalitha et al., (2014) worked on Tributylin chloride action on alkaline and acid phosphatase activity in estuarine clam, Anadara rhombea. Acid or alkaline Phosphatases activity studied in crabs, fishes, mollusc and gastropods by Joshi and Desai (1981); Surendran (1994); Sontakke and Jadhav (1997); Seitkalvia et al., (2015).

The catabolic effects are altered or induced by the different chemicals. The whole enzyme system became imbalanced and creates a hypersensitive condition against the toxic effect caused by the antibiotics. The impact of antibiotics, tetracycline on the enzyme activity is not yet been reported. Freshwater bivalves are used for artificial pearl culture as the demand for pearl in market increasing day by day. To fulfill this demand through reduction in mortality, antibiotic treatment in water is given to the bivalves after inserting beads in the mantle, gonad or other tissues. The effect of this treatment on the physiology of bivalve is unknown, but certainly stress caused due to the antibiotic treatment causes alteration in enzyme parameters.

\section{Bioassay:}

\section{Methods And Material}

Freshwater bivalves Parreysia cylindrica were collected from Girna Dam Dist: Nasik (M.S.) India situated at $20^{\circ} 28^{\prime} 58^{\prime \prime} \mathrm{N}$ latitude and $74^{\circ} 43^{\prime} 13^{\prime \prime} \mathrm{E}$ longitude. After cleaning of shells to remove fouling matter, the animals were acclimatized for 4 days. Water temperature during the experimentation was $28.5^{\circ} \mathrm{C} \pm 2.0^{\circ} \mathrm{C}$ and $\mathrm{pH} 7.3 \pm 0.23$. Healthy $P$. cylindrica ( 25 to $40 \mathrm{~mm}$ length) divided into three groups as acute and chronic treated groups along with control. For acute exposure to Tetracycline dose used was 166.54PPM for Parreysia cylindrica upto 96 hours while chronic exposure dose was 73.82 PPM up to 21 days. Control set was provided with dechlorinated water only without addition of any antibiotics. The estimation of alkaline phosphatase was carried out in mantle, gills and digestive glands of $P$. cylindrica after acute and chronic exposures. The tissues were removed, washed thoroughly in ice-cold distilled water and $10 \%(\mathrm{w} / \mathrm{v})$ homogenate was prepared by using carbonate-bicarbonate buffer of $\mathrm{pH} 10$ for enzyme assay. Each homogenate was centrifuged at $5000 \mathrm{rpm}$ for 10 minutes and from that $1 \mathrm{ml}$ of supernatant was used for assay. The boiled homogenate of the respective extract was used as a blank. The standard curve calibration was done to evaluate the enzymatic level. In the present 
work alkaline phosphatase activity was measured by the method of King (1951). The reaction mixture consisted of $1 \mathrm{ml}(0.01 \mathrm{M})$ disodium phenyl phosphate, $2 \mathrm{ml}$ carbonate-bicarbonate buffer $(\mathrm{pH} 10)$ and $0.5 \mathrm{ml}$ tissue homogenate. It was incubated at $37^{\circ} \mathrm{C}$ for $1 \mathrm{hr}$. The reaction was terminated by the addition of $1 \mathrm{ml} \mathrm{Folin}$ Ciocaltaeu phenol reagent and centrifuged at $2000 \mathrm{rpm}$ for $10 \mathrm{~min}$. To the supernatant $2 \mathrm{ml}$ of $15 \%$ sodium carbonate was added. The blue colour complex developed was read at $660 \mathrm{~nm}$. The blank readings were obtained without incubation. The calibration of standard curve was developed by using phenol as a standard. The activity was expressed as $\mathrm{KA}$ unit/gm/hr at $37^{\circ} \mathrm{C}$ at $\mathrm{pH} 10.0$. The data of three replicates used to find out standard deviation and application of Student's t test at $0.001,0.01$ and 0.05 level of probability used to study level of significance.

\section{Observation And Results}

After acute exposures of tetracycline, alkaline phosphatase activity was estimated in mantle gill and digestive gland of $P$. cylindrica where highest content found in digestive gland and least in gills. (Fig. 1 and Fig. $2)$. During acute exposure digestive gland affected least $(+12.66 \%)$ but gills showed high increase $(+26.37 \%)$ than mantle while after chronic exposure it showed $25.32 \%$ increase upto $14^{\text {th }}$ day and then reached to $16.55 \%$ increase upto $21^{\text {st }}$ day in gills over control (Table 2).

Table 1: Alkaline phosphatase activity in different tissues of Parreysia cylindrica after acute exposure to Tetracycline

\begin{tabular}{|l|l|l|l|l|}
\hline \multirow{2}{*}{ Tissues } & \multicolumn{2}{|c|}{ 24 hrs } & \multicolumn{2}{c|}{ 96 hrs } \\
\cline { 2 - 5 } & Control & Tetracycline & Control & Tetracycline \\
\hline Mantle & 0.7535 & 0.8163 & 0.7629 & 0.8646 \\
& \pm 0.0433 & \pm 0.0014 & \pm 0.0695 & \pm 0.0655 \\
& & $+8.3438^{*}$ & 0.4411 & $+13.3333^{*}$ \\
\hline Gill & 0.4823 & 0.5175 & \pm 0.0283 & 0.5574 \\
& \pm 0.0114 & \pm 0.00983 & & \pm 0.0491 \\
& & $+7.3043^{* * *}$ & 0.7904 & $+26.3768 * *$ \\
\hline D. gland & 0.8824 & 0.8448 & \pm 0.0851 & \pm 0.8905 \\
& \pm 0.0248 & \pm 0.0156 & & \pm 0.0912 \\
& & $-4.2608^{*}$ & & $+12.6666^{* *}$ \\
\hline
\end{tabular}

Where $\mathrm{M}=$ Mantle; $\mathrm{G}=$ Gill; $\mathrm{DG}=$ Digestive gland.

Values expressed as KA unit/gm/hr at $37^{\circ} \mathrm{C}$.

\pm indicates standard deviation of three independent replications.

+ or $-\%$ variation over control. Significance: $* \mathrm{P}<0.05 ; * * \mathrm{P}<0.01$; *** $\mathrm{P} 0.001$; NS = Non-significant.

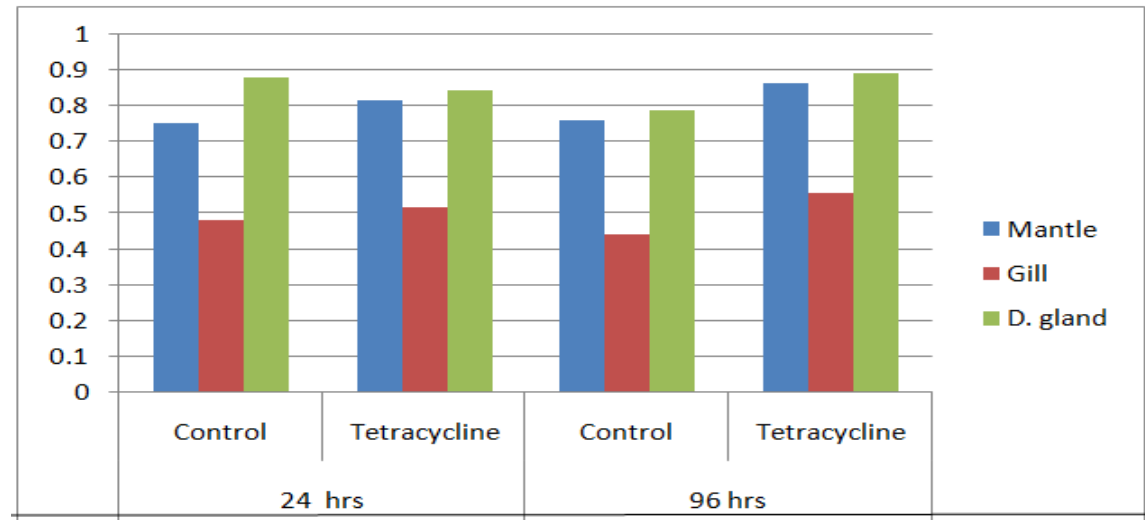

Fig 1: Alkaline phosphatase activity in different tissues of $P$. cylindrica after acute exposure to Tetracycline

Table 2: Alkaline phosphatase activity in different tissues of $\boldsymbol{P}$. cylindrica after chronic exposure to Tetracycline

\begin{tabular}{|c|c|c|c|c|c|c|}
\hline \multirow[t]{2}{*}{ Tissues } & \multirow{2}{*}{\begin{tabular}{|l|}
7 days \\
Control
\end{tabular}} & \multirow[b]{2}{*}{ Tetracycline } & \multicolumn{2}{|c|}{14 days } & \multicolumn{2}{|c|}{21 days } \\
\hline & & & Control & Tetracycline & Control & Tetracycline \\
\hline Mantle & $\begin{array}{l}0.6110 \\
+0.0547\end{array}$ & $\begin{array}{l}0.6637 \\
+0.0192 \\
+8.6266 \mathrm{NS}\end{array}$ & $\begin{array}{l}0.6000 \\
+0.0566\end{array}$ & $\begin{array}{l}0.6657 \\
+0.0320 \\
+10.9568 *\end{array}$ & $\begin{array}{l}0.5682 \\
+0.0233\end{array}$ & $\begin{array}{l}0.6409 \\
+0.0441 \\
+12.8115^{*}\end{array}$ \\
\hline Gill & $\begin{array}{l}0.4126 \\
\pm 0.0122\end{array}$ & $\begin{array}{l}0.4419 \\
\pm 0.0217 \\
+7.1014 * \\
\end{array}$ & $\begin{array}{l}0.4135 \\
\pm 0.0081\end{array}$ & $\begin{array}{l}0.5182 \\
\pm 0.0057 \\
+25.3257 \text { *** } \\
\end{array}$ & $\begin{array}{l}0.4090 \\
\pm 0.0699\end{array}$ & $\begin{array}{l}0.4766 \\
\pm 0.0575 \\
+16.5506^{*} \\
\end{array}$ \\
\hline
\end{tabular}

Where $\mathrm{M}=$ Mantle; $\mathrm{G}=$ Gill; $\mathrm{DG}=$ Digestive gland.

Values expressed as KA unit/gm/hr at $37^{\circ} \mathrm{C}$.

\pm indicates standard deviation of three independent replications.

+ or $-\%$ variation over control. Significance: $* \mathrm{P}<0.05$; ** $\mathrm{P}<0.01$; *** $\mathrm{P} 0.001$; NS = Non-significant. 


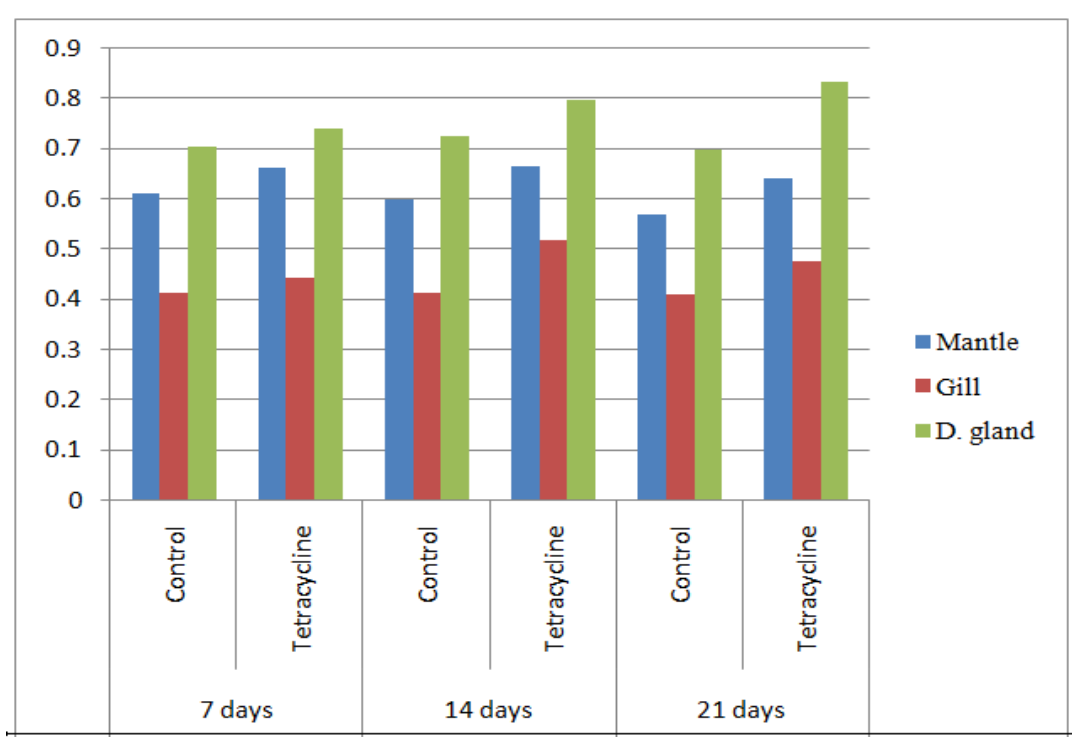

Fig. 2: Alkaline phosphatase activity in different tissues of $P$. cylindrica after chronic exposure to Tetracycline

\section{Discussion}

As alkaline phosphatase acts as a bioindicator to know about the presence of pollutants, heavy metals and action on aquatic animals and in this study toxic stress due to antibiotics in freshwater bivalve $P$. cylindrica assessed. Alkaline phosphatase activity showed marked increase in shell regeneration also. (Chan, 1971). Gupta and Gupta, (1977) observed increased alkaline phosphatase activity in the frog, Rana tigerina infected with Ganeo tigrinium. Lomte and Godhamgaonkar, (1983) found the increased activity of acid and alkaline phosphatase in Thiara tuberculata due to trematode infection and reported that the rise in alkaline phosphatase activity in the infected snail was more than acid phosphatase. Change in the enzyme activity shows the stress in any organism resulting in metabolic burden (Hansen, et al., 1992). The increase in alkaline phosphatase may be due to energy breakdown pathway by phosphorylation. It indicates high phosphorylation to compensate transportation of molecules through plasma membrane. As per different studies showed increase in alkaline phosphatase activity due to pollutant effect, in this study also it might be due to induced stress by tetracycline leads to a need for transportation of different molecules across the plasma membrane to cope up the problem of toxic effect caused due to tetracycline.

\section{Conclusion}

The present work focuses on the tetracycline induced stress which leads to change in alkaline phosphatase activity. Due to this stress the alkaline phosphatase activity increases mainly in gills being a largest surface area exposed directly to the contents of the water, affecting the organ more than the mantle and digestive gland in $P$. cylindrica during acute exposure. During chronic exposure it increased maximum in gills upto $14^{\text {th }}$ day and later become less, might be due to rescue of bacterial infection by tetracycline treatment.

\section{Acknowledgements}

Author is grateful to the Head of B.P. Arts, S.M.A. Sci. and K.K.C. Comm. College for providing facilities for the present work and also Head, Deptt. Of Zoology, Sant Gadge Baba Amravati University

\section{Journal Papers:}

\section{References}

[1]. Ranilalitha P., Sukumaran1 M. and Raveendran S., (2014) Effect of TBTCL on phosphatases activity in estuarine edible clam, Anadara rhombea Born (Bivalvia: Mollusca) International Journal of Pure and Applied Zoology, Vol.2(4): 315-320.

[2]. Joshi, V.M. and Desai, A.K., (1981) Effect of sublethal concentration of monocrotophos on acid and alkaline phosphatases activities in the tissues of freshwater fish, Tilapia mossambica. J. Anim. Morphol. Physiol. 28: 221-228.

[3]. Surendran, S. (1994) Levels of Alkaline and acid phosphatases in the brain of fish. Ecotoxicol. Environ. Monit. 4(1): 71-73.

[4]. Sonatakke, and Sunita Jadhav, (1997) Changes in the acid and alkaline phosphabase activity in the tissues of Thiara tuberculata after exposure to heavy metals, Ind. J. Environ. Toxicol., 7(1): 32-35.

[5]. Hansen, J.I., Mustafa, T. and Depledge, M.,(1992) Mechanism of copper toxicity in the shore crab, Carcinus moenas. Mar. Biol.,114(2): 253-257.

[6]. Ballantyne, J.S. and Moon, T.W. (1985) Hepatopancreas mitochondria from Mytilus edulis: Substrate preferences and effects of $\mathrm{pH}$ and osmolarity. Marine Biology 87: 239-244.

[7]. Gupta, S.P. and Gupta, R.C., (1977) Phosphatase activity in Ganeo tigrinum from Rana tigrina. Z. Parasitol., 54: 89-94.

[8]. Lomte V.S. and Godhamgaonkar, U., (1983) Lysosomal enzymes and trematode infection in a snail, Thiara tuberculata (Muller) J. Environmental Biol. 5: 181-184.

Books:

[9]. King, E. J., (1951) In: Micro-analysis in medical biochemistry. $2^{\text {nd }}$ Edn. Churchill, London, U. K. 